Giving Meaning to Economic, Social, and Cultural Rights 
Pennsylvania Studies in Human Rights

Bert B. Lockwood, Jr., Series Editor

A complete list of books in the series is available from the publisher. 


\section{Giving Meaning to Economic, Social, and Cultural Rights}

Edited by

ISFAHAN MERALI and VALERIE OOSTERVELD

$\overline{\text { PENN }}$

University of Pennsylvania Press

Philadelphia 
Copyright (c) 2001 University of Pennsylvania Press

All rights reserved

Printed in the United States of America on acid-free paper

10988765543221

Published by

University of Pennsylvania Press

Philadelphia, Pennsylvania 19104-4011

Library of Congress Cataloging-in-Publication Data

Giving meaning to economic, social, and cultural rights / edited by Isfahan Merali and Valerie Oosterveld.

p. cm. - (Pennsylvania studies in human rights)

Includes bibliographical references and index.

ISBN 0-8122-3601-7 (alk. paper)

1. Human rights. 2. Social policy. 3. Economic policy. 4. Cultural policy. 5. Women's rights. I. Merali, Isfahan. II. Oosterveld, Valerie. III. Series.

JC571.R396 2001

$323-\mathrm{dc} 21$

2001027019 